\title{
Does the risk of stomach cancer remain among second-generation immigrants in Sweden?
}

\author{
Seyed Mohsen Mousavi $\cdot$ Kristina Sundquist • \\ Kari Hemminki
}

Received: 29 June 2011/Accepted: 28 August 2011/Published online: 1 October 2011

(C) The International Gastric Cancer Association and The Japanese Gastric Cancer Association 2011

\begin{abstract}
The observed increased risks of noncardia stomach cancer among foreign-born second-generation immigrants compared to the Swedes suggest that these immigrants were infected by Helicobacter pylori before immigration.
\end{abstract}

Keywords Cancer $\cdot$ Helicobacter pylori $\cdot$ Infection · Risk · Second-generation immigrants $\cdot$ Stomach $\cdot$ Sweden

Previous descriptive epidemiological studies have shown that the risk of stomach cancer is influenced by environmental factors, in particular by Helicobacter pylori infection and diet [1]. However, the interaction between genetic susceptibility and environmental factors is suggested to play an important role in the etiology of stomach cancer $[2,3]$. Several observations indicate that stomach cancer in the cardia region is etiologically different from that in the noncardia region $[4,5]$. For example, the association of $H$. pylori infection with the risk of stomach cancer is restricted to the noncardia region, while the cardia region shares the same risk factors as the distal part of esophagus, for which an inverse association of $H$. pylori infection with

S. M. Mousavi $(\varangle) \cdot$ K. Hemminki

Division of Molecular Genetic Epidemiology, German Cancer

Research Center (DKFZ), CO50, Im Neuenheimer Feld 580,

69120 Heidelberg, Germany

e-mail: m.mousavi@dkfz.de

S. M. Mousavi

Cancer Institute, Tehran University of Medical Sciences,

Tehran, Iran

K. Sundquist $\cdot$ K. Hemminki

Center for Primary Health Care Research, Lund University,

Malmö, Sweden esophageal adenocarcinoma has been reported [4, 6-8]. It has been found that diet and smoking is associated with the risk of cancer in both stomach regions $[4,9,10]$.

Although there are controversies regarding the influence of migration on the risk of stomach cancer [11-13], our previous study showed an increased risk of stomach cancer risk among first-generation immigrants in Sweden. It was suggested that childhood infection with $H$. pylori would be a possible cause $[14,15]$. The prevalence of $H$. pylori varies from more than $80 \%$ among middle-aged adults in developing countries to less than $20 \%$ in developed countries $[15,16]$. A change in the seroprevalence of $H$. pylori to the rate of that in host country has been reported among secondgeneration immigrants whose parents moved from high-risk countries [17, 18]. However, the effect of migration on the risk of stomach cancer through the next generations is still unclear and there is no study in the current literature, to our knowledge, exploring the risk of stomach cancer by site among second-generation immigrants [19-21]. In this report, as a subpopulation of our previous publication, we studied the risk of stomach cancer among second-generation immigrants by tumor site, in 304 stomach cancer cases, which is some 7 times the number of cases in previous publications on the same topic [14, 19-21].

We used the updated version of the Swedish FamilyCancer Database (FCD) [22]. Data on cancers in the FCD are coded based on the 7th revision of the International Classification of Disease (ICD), with stomach cancer coded as 151. The FCD has used the ICD-9 classification from 1987 onward, which codes cardia as 1510 and noncardia as 1511-1516, 1518, and 1519. The second-generation immigrants were defined as Swedish-born or foreign-born with identified mothers in the database. As in our previous studies, the expected number of cases and the standardized incidence ratios (SIRs) were calculated [23-25]. We used 
the native Swedes as the reference population. To capture the maximum number of cases, the second-generation immigrants were classified based on the risk of stomach

Table 1 Standardized incidence ratios (SIRs) for stomach cancer among second-generation immigrants to Sweden from 1958 to 2008

\begin{tabular}{|c|c|c|c|c|c|}
\hline \multirow{2}{*}{$\begin{array}{l}\text { Birth region } \\
\text { of mother }\end{array}$} & \multirow{2}{*}{$\begin{array}{l}\text { Birth region of } \\
\text { second generation }\end{array}$} & \multicolumn{4}{|c|}{ Stomach cancer } \\
\hline & & $N$ & SIR & $95 \%$ & \\
\hline Sweden & Sweden & 3,345 & 1.00 & & \\
\hline \multirow[t]{2}{*}{ High-risk countries } & Sweden & 92 & 1.22 & 0.98 & 1.49 \\
\hline & High-risk countries & 133 & $\underline{2.06}$ & 1.73 & 2.44 \\
\hline \multirow[t]{2}{*}{ Other countries } & Sweden & 55 & 1.16 & 0.88 & 1.52 \\
\hline & Other countries & 21 & 1.77 & 1.09 & 2.70 \\
\hline \multirow[t]{2}{*}{ All immigrants } & Sweden & 149 & 1.20 & 1.02 & 1.41 \\
\hline & All immigrants & 155 & 1.99 & 1.69 & 2.33 \\
\hline
\end{tabular}

Bold non-underlined SIRs values: $95 \%$ CI does not include 1.00. Bold underlined SIRs: higher than 1.00 at the $1 \%$ confidence level

High-risk countries: Finland, Baltic countries, Germany, Poland, Eastern Europe, Russia, former Yugoslavia, Greece, Southern Europe, Turkey, Iraq, Southeast Asia, East Asia, Chile, and Latin America. Other countries: Denmark, Norway, United Kingdom, Iran, Asian Arab countries: Lebanon, Syria, United Arab Emirates, Bahrain, Brunei, Gaza, Strip, Jordan, Kuwait, Oman, Palestine, Qatar, Saudi Arabia, South Yemen and Yemen. Indian Subcontinent, North America, and Africa cancer observed in the first-generation immigrants in our previous report ("high-risk" countries: SIR was significantly increased and "other" countries: SIR was not significant) and based on the birth region of the mothers [14]. As the sex-specific analysis showed no differences in the risk of stomach cancer, the data were analyzed together for both sexes. The histology-specific risk of esophageal cancer, WHO/HS/CANC/24.1 Histology Code, "PAD": adenocarcinoma $(\mathrm{PAD}=96)$ and squamous-cell carcinoma $(\mathrm{PAD}=146)$ was also calculated to examine the effect of H. pylori infection from $1958[4,6]$. Confidence intervals $(95 \% \mathrm{CI})$ were calculated assuming a Poisson distribution, and a $P$ value of less than 0.05 was considered as statistically significant. A $P$ value of 0.01 was also used to minimize chance findings [26]. SAS software version 9.2 was used for the data analysis (SAS Institute, Cary, NC, USA).

Our data showed that the risk of stomach cancer was increased among foreign-born second-generation immigrants whose mothers had moved from "high-risk" countries (SIR $=2.06$ ) or from "other" countries (1.77) (Table 1). The total number of stomach cancer cases with a defined site in the FCD was 3,446, and 282 of them were diagnosed in second-generation immigrants (Table 2).

Table 2 Standardized incidence ratios (SIRs) for stomach cancer by site and esophageal cancer by histology among second-generation immigrants to Sweden

\begin{tabular}{|c|c|c|c|c|c|c|c|c|c|}
\hline \multirow[t]{2}{*}{ Birth region of mother } & \multirow[t]{2}{*}{ Birth region of second generation } & \multicolumn{4}{|c|}{ Stomach cancer $^{\mathrm{a}}$} & \multicolumn{4}{|c|}{ Esophageal cancer ${ }^{\mathrm{b}}$} \\
\hline & & $N$ & SIR & \multicolumn{2}{|c|}{$95 \% \mathrm{CI}$} & $N$ & SIR & \multicolumn{2}{|c|}{$95 \% \mathrm{CI}$} \\
\hline & & \multicolumn{4}{|l|}{ Cardia } & \multicolumn{4}{|c|}{ Squamous-cell carcinoma } \\
\hline Sweden & Sweden & 928 & 1.00 & & & 754 & 1.00 & & \\
\hline \multirow[t]{2}{*}{ High-risk countries } & Sweden & 25 & 1.14 & 0.74 & 1.69 & 14 & 1.04 & 0.57 & 1.74 \\
\hline & High-risk countries & 23 & 1.26 & 0.80 & 1.89 & 18 & 1.37 & 0.81 & 2.17 \\
\hline \multirow[t]{2}{*}{ Other countries } & Sweden & 14 & 1.05 & 0.57 & 1.76 & 5 & 0.51 & 0.16 & 1.18 \\
\hline & Other countries & 3 & 0.89 & 0.18 & 2.61 & 3 & 1.26 & 0.26 & 3.69 \\
\hline \multirow[t]{3}{*}{ All immigrants } & Sweden & 40 & 1.13 & 0.80 & 1.53 & 20 & 0.85 & 0.52 & 1.31 \\
\hline & All immigrants & 26 & 1.18 & 0.77 & 1.72 & 21 & 1.33 & 0.82 & 2.03 \\
\hline & & \multicolumn{4}{|c|}{ Noncardia } & \multicolumn{4}{|c|}{ Adenocarcinoma } \\
\hline Sweden & Sweden & 2,236 & 1.00 & & & 704 & 1.00 & & \\
\hline \multirow[t]{2}{*}{ High-risk countries } & Sweden & 62 & 1.24 & 0.95 & 1.59 & 23 & 1.50 & 0.95 & 2.25 \\
\hline & High-risk countries & 100 & $\underline{2.33}$ & 1.90 & 2.83 & 9 & 0.68 & 0.31 & 1.28 \\
\hline \multirow[t]{2}{*}{ Other countries } & Sweden & 36 & 1.15 & 0.80 & 1.59 & 9 & 0.91 & 0.42 & 1.72 \\
\hline & Other countries & 17 & $\underline{2.15}$ & 1.25 & 3.44 & 6 & 2.45 & 0.90 & 5.34 \\
\hline \multirow[t]{2}{*}{ All immigrants } & Sweden & 99 & 1.21 & 0.98 & 1.47 & 32 & 1.26 & 0.86 & 1.78 \\
\hline & All immigrants & 117 & 2.25 & 1.86 & 2.70 & 15 & 0.93 & 0.52 & 1.53 \\
\hline
\end{tabular}

Significant SIRs: $95 \%$ CI does not include 1.00, and bold underlined SIRs were higher than 1.00 at the $1 \%$ confidence level

a Based on ICD-9 classification from 1987 to 2008

b Based on PAD classification from 1958 to 2008

High-risk countries: Finland, Baltic countries, Germany, Poland, Eastern Europe, Russia, former Yugoslavia, Greece, Southern Europe, Turkey, Iraq, Southeast Asia, East Asia, Chile, and Latin America. Other countries: Denmark, Norway, United Kingdom, Iran, Asian Arab countries: Lebanon, Syria, United Arab Emirates, Bahrain, Brunei, Gaza, Strip, Jordan, Kuwait, Oman, Palestine, Qatar, Saudi Arabia, South Yemen and Yemen. Indian Subcontinent, North America, and Africa 
An increased risk of noncardia cancer was observed among foreign-born second-generation immigrants whose mothers had moved from "high-risk" countries (2.33) or from "other" countries (2.15). No increased risk of cardia cancer was observed in the second-generation immigrants. A nonsignificant decreased risk of esophageal adenocarcinoma was observed among foreign-born second-generation immigrants whose mothers had moved from "high-risk" countries $(\mathrm{SIR}=0.68,95 \% \mathrm{CI}=0.31-1.28$ ).

In conclusion, the present data showed that the risk of noncardia stomach cancer was increased only among foreign-born second-generation immigrants. A likely explanation is that these immigrants were infected by $H$. pylori before immigration.

Acknowledgments This study was supported by the German Cancer Research Center (DKFZ), Deutsche Krebshilfe, the Swedish Cancer Society, the Swedish Council for Working Life and Social Research, and the Europe and EU FP7/2007-2013 grant 260715. The authors would also like to thank Miss Parisa Roudgari for English proofreading.

\section{References}

1. Boyle P, Levin B. World cancer report 2008. Lyon: IARC; 2008.

2. Ando T, Goto Y, Ishiguro K, Maeda O, Watanabe O, Ohmiya N, et al. The interaction of host genetic factors and Helicobacter pylori infection. Inflammopharmacol. 2007;15(1):10-4.

3. Gonzalez CA, Lopez-Carrillo L. Helicobacter pylori, nutrition and smoking interactions: their impact in gastric carcinogenesis. Scand J Gastroenterol. 2010;45(1):6-14.

4. Lochhead $\mathrm{P}$, El-Omar EM. Gastric cancer. $\mathrm{Br}$ Med Bull. 2008;85:87-100.

5. Hansen S, Vollset SE, Derakhshan MH, Fyfe V, Melby KK, Aase $\mathrm{S}$, et al. Two distinct aetiologies of cardia cancer; evidence from premorbid serological markers of gastric atrophy and Helicobacter pylori status. Gut. 2007;56(7):918-25.

6. Islami F, Kamangar F. Helicobacter pylori and esophageal cancer risk: a meta-analysis. Cancer Prev Res (Phila). 2008;1(5):329-38.

7. Gastric cancer and Helicobacter pylori: a combined analysis of 12 case control studies nested within prospective cohorts. Gut. 2001;49(3):347-53.

8. Souza RF, Spechler SJ. Concepts in the prevention of adenocarcinoma of the distal esophagus and proximal stomach. CA Cancer J Clin. 2005;55(6):334-51.

9. Plummer M, Franceschi S, Munoz N. Epidemiology of gastric cancer. IARC Sci Publ. 2004;157:311-26.

10. Ladeiras-Lopes R, Pereira AK, Nogueira A, Pinheiro-Torres T, Pinto I, Santos-Pereira R, et al. Smoking and gastric cancer: systematic review and meta-analysis of cohort studies. Cancer Causes Control. 2008;19(7):689-701.

11. Lee J, Demissie K, Lu SE, Rhoads GG. Cancer incidence among Korean-American immigrants in the United States and native Koreans in South Korea. Cancer Control. 2007;14(1):78-85.

12. Tsugane S, de Souza JM, Costa ML Jr, Mirra AP, Gotlieb SL, Laurenti R, et al. Cancer incidence rates among Japanese immigrants in the city of Sao Paulo, Brazil, 1969-78. Cancer Causes Control. 1990;1(2):189-93.

13. Kamineni A, Williams MA, Schwartz SM, Cook LS, Weiss NS. The incidence of gastric carcinoma in Asian migrants to the United States and their descendants. Cancer Causes Control. 1999;10(1):77-83.

14. Mousavi SM, Sundquist J, Hemminki K. Does immigration play a role in the risk of gastric cancer by site and by histological type? A study of first-generation immigrants in Sweden. Gastric Cancer. 2011;14(3):285-9.

15. Suerbaum S, Michetti P. Helicobacter pylori infection. N Engl J Med. 2002;347(15):1175-86.

16. Verdu EF, Fraser R, Tiberio D, Herranz M, Sipponen P, Blum $\mathrm{AL}$, et al. Prevalence of Helicobacter pylori infection and chronic dyspeptic symptoms among immigrants from developing countries and people born in industrialized countries. Digestion. 1996;57(3):180-5.

17. Porsch-Ozcurumez M, Doppl W, Hardt PD, Schnell-Kretschmer $\mathrm{H}$, Tuncay M, Akinci A, et al. Impact of migration on Helicobacter pylori seroprevalence in the offspring of Turkish immigrants in Germany. Turk J Pediatr. 2003;45(3):203-8.

18. Tsai CJ, Perry S, Sanchez L, Parsonnet J. Helicobacter pylori infection in different generations of Hispanics in the San Francisco Bay Area. Am J Epidemiol. 2005;162(4):351-7.

19. Hemminki K, Li X. Cancer risks in Nordic immigrants and their offspring in Sweden. Eur J Cancer. 2002;38(18):2428-34.

20. Bendesky A, Ostrosky-Wegman P. On cancer risks in secondgeneration immigrants to Sweden. Int J Cancer. 2002;101(3):298. Author reply 9.

21. Hemminki K, Li X. Cancer risks in second-generation immigrants to Sweden. Int J Cancer. 2002;99(2):229-37.

22. Hemminki K, Ji J, Brandt A, Mousavi SM, Sundquist J. The Swedish Family-Cancer Database 2009: prospects for histologyspecific and immigrant studies. Int J Cancer. 2009;126(10): 2259-67.

23. Mousavi SM, Sundquist J, Hemminki K. Risk of transitional-cell carcinoma of the bladder in first- and second-generation immigrants to Sweden. Eur J Cancer Prev. 2010;19(4):275-9.

24. Mousavi SM, Sundquist J, Hemminki K. Nasopharyngeal and hypopharyngeal carcinoma risk among immigrants in Sweden. Int J Cancer. 2010;127(12):2888-92.

25. Mousavi SM, Brandt A, Sundquist J, Hemminki K. Esophageal cancer risk among immigrants in Sweden. Eur J Cancer Prev. 2011;20(2):71-6.

26. Stigler S. Fisher and the 5\% level. Chance. 2008;21(4):12. 